Jurnal Keperawatan Silampari

Volume 5, Nomor 1, Desember 2021

e-ISSN: 2581-1975

p-ISSN: 2597-7482

DOI: https://doi.org/10.31539/jks.v5i1.2709

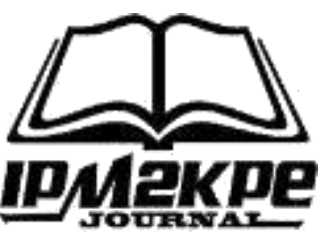

\title{
KECEMASAN ORANG TUA KETIKA ANAK BERINTERAKSI SOSIAL DI MASA PANDEMI COVID-19
}

\author{
Padila $^{1}$, Dhea Septeah Ningrum ${ }^{2}$, Juli Andri ${ }^{3}$, Andry Sartika ${ }^{4}$, \\ Muhammad Bagus Andrianto \\ Universitas Muhammadiyah Bengkulu ${ }^{1,2,3,4,5}$ \\ padila@umb.ac.id ${ }^{1}$
}

\begin{abstract}
ABSTRAK
Penelitian ini bertujuan untuk melihat gambaran tingkat kecemasan orang tua ketika anak berinteraksi sosial di masa pandemi COVID-19 di wilayah kerja Puskesmas Beringin Raya Kota Bengkulu. Metode penelitian yang digunakan dalam penelitian ini adalah metode deskriptif dengan pendekatan kuantitatif. Hasil penelitian menunjukkan bahwa gambaran tingkat kecemasan orang tua ketika anak berinteraksi sosial di masa pandemi COVID-19 dari 45 responden, kategori tidak cemas sebanyak 5 responden $(11.1 \%)$, tingkat cemas ringan berjumlah 37 responden (82.2\%), dan cemas sedang sebanyak 3 responden $(6.7 \%)$. Simpulan, gambaran tingkat kecemasan orang tua ketika anak berinteraksi sosial di masa pandemi COVID-19 di wilayah kerja puskesmas Beringin Raya Kota Bengkulu sebagian besar tergolong kecemasan ringan.
\end{abstract}

Kata Kunci: Kecemasan, Orang Tua, Pandemi COVID-19

\section{ABSTRACT}

This study aims to describe the level of parental anxiety when children interact socially during the COVID-19 pandemic in the work area of the Beringin Raya Public Health Center, Bengkulu City. The research method used in this study is a descriptive method with a quantitative approach. The results showed that the description of the level of anxiety of parents when their children interacted socially during the COVID-19 pandemic from 45 respondents, the category of not being anxious was five respondents $(11.1 \%)$, mild anxiety was 37 respondents (82.2\%), and moderate anxiety was three respondents. (6.7\%). In conclusion, the description of the level of anxiety of parents when children interact socially during the COVID-19 pandemic in the work area of the Beringin Raya Public Health Center in Bengkulu City is mainly classified as mild anxiety.

Keywords: Anxiety, Parents, COVID-19 Pandemic

\section{PENDAHULUAN}

COVID-19 adalah penyakit menular yang disebabkan oleh jenis Corona Virus yang baru ditemukan, yang pertama kali terjadi di Wuhan Tingkok pada bulan Desember 2019. Adapun gelaja COVID-19 yang paling umum adalah demam, rasa lelah, dan batuk kering, rasa nyeri sakit, hidung tersumbat, pilek, sakit tenggorokan atau diare. COVID-19 dapat menyebar dari orang ke orang melalui percikan-percikan dari hidung atau mulut yang keluar saat orang yang terjangkit COVID-19 batuk (Iftitah \& Anawaty, 2020). 
Berita mengenai Virus Corona atau yang dikenal juga dengan nama COVID-19 (Corona Virus Desease-19) telah menjadi konsumsi harian masyarakat Indonesia, bahkan banyak Negara di dunia, sejak diumumkannya virus corona sebagai pandemic global setelah jumlah infeksi di seluruh dunia mencapai lebih dari 121.000 kasus. Berdasarkan data terakhir yang terdapat dalam website WHO (2020) hingga 1 Juli 2020 total kasus COVID-19 di dunia terkonfirmasi sebanyak 10.571.525 dari jumlah tersebut sebanyak 5.782.769 pasien telah sembuh dan 513.122 orang meninggal dunia.

Di negara Indonesia sendiri, data terakhir pada 1 Juli 2020 diketahui ada kasus COVID-19 berjumlah kasus positif menjadi 47.896 kasus, 27.568.241 pasien dinyatakan sembuh, 3.036 meninggal, Indonesia menjadi negara ke-29 di dunia dengan jumlah kasus terbanyak. Sementara di Asia, Indonesia berada di urutan ke-9 dan selisih puluhan ribu kasus tepat di bawah China. Penambahan terbanyak tercatat di DKI Jakarta sebanyak 142 kasus, Sulawesi Selatan 112 kasus, Jawa Tengah 99 kasus dan Kalimantan 94 kasus (Kompas, 2020). Di Provinsi Bengkulu sendiri data terakhir pada 23 Juni 2020 tercatat 118 positif, 72 sembuh dan 9 meninggal (Gugus COVID-19, 2020).

Sejak adanya pandemi COVID-19, banyak sekali perubahan besar yang terjadi pada berbagai macam aspek kehidupan kita. Salah satu yang paling terasa adalah keharusan untuk menerapkan physical distancing dan mengurangi bepergian ke luar rumah bila tidak ada kepentingan yang mendesak guna memutus rantai penularan COVID-19. Paling depan adalah 3M, karena penyebabnya penyakit menular yang bisa dicegah. Rute penularan dari saluran pernafasan oleh karenanya yang dilindungi adalah pernafasan dengan masker. 3M tersebut terdiri dari memakai masker, menjaga jarak dan mencuci tangan pakai sabun (Kemenkes RI, 2020). Pemerintah telah melakukan berbagai upaya pencegahan untuk mengatasi penyebaran virus ini daripada menyebar dengan cepat, seperti bekerja dari rumah (WFH), social distancing, PSBB, dll (Tursina, 2020; Andri et al., 2021).

WHO (2020) telah mengingatkan bahaya kecemasan ditengah pandemi melalui situs resminya. Menurut informasi CNN Indonesia (2020) pandemi COVID-19 membawa perubahan yang drastis bagi banyak anak dan orang tua. Kondisi orang tua yang kerap merasa khawatir dan cemas ketika anaknya berinteraksi di luar rumah ditambah hilangnya aktivitas bermain seperti biasa membuat anak rentan pula terserang perasaan cemas. Kecemasan berlebih bisa membuat kesehatan seseorang terganggu dan terkena psikosomatik.

Dari hasil penelitian yang dilakukan oleh Megatsari (2020) diketahui bahwa pada responden kelompok usia 20-29 tahun 4,33 kali lebih mungkin mengalami kecemasan dengan level yang lebih tinggi dari gangguan kecemasan yang dialami oleh kelompok usia 50 tahun. Hasil tersebut menunjukkan bahwa orang yang lebih tua cenderung jarang mengalami tingkat gangguan kecemasan yang tinggi. Begitupula hasil penelitian Padila et al., (2021) yang menyatakan ibu usia remaja maupun ibu dengan orang tua tunggal lebih banyak mengalami tingkat kecemasan dengan level sedang di masa pandemi COVID-19.

Dari survey ke 10 orang tua yang dilakukan pada tanggal 2 Desember 2020 di wilayah kerja Puskesmas Beringin Raya dengan kategori perempuan sebanyak 4 orang, laki-laki sebanyak 6 orang, mendapatkan hasil bahwa 10 responden tersebut mengatakan cemas jika anaknya tertular COVID-19 pada saat bermain dengan teman-temannya. Ke 10 orang tua tersebut mengatakan mereka sudah dengan menjelaskan bahaya virus COVID-19, orang tua juga sudah berusaha memberikan fasilitas bermain untuk anaknya namun mereka tetap ingin bermain dengan teman-temannya. Maka dari itu orang tua mengizinkan anakanaknya bermain diluar dengan tetap melalukan protokol kesehatan yang dianjurkan yaitu menggunakan masker menjaga jarak dan mencuci tangan. 
Penelitian tentang kecemasan orang tua ketika anak berinteraksi sosial di masa pandemi COVID-19 ini masih jarang dilakukan, khususnya penelitian ini belum pernah dilakukan di tempat penelitian.

\section{METODE PENELITIAN}

Dalam penelitian ini digunakan metode deskriptif dengan pendekatan kuantitatif, peneliti bermaksud untuk mengetahui secara faktual mengenai gambaran tingkat kecemasan orang tua dalam mendampingi anak berinteraksi sosial dimasa pandemi COVID-19. Alat ukur yang digunakan adalah kuesioner. Tingkat kecemasan diukur dengan menggunakan kuesioner HARS (Hamilton Anxiety Rating Scale). HARS terdiri dari 14 pertanyaan dan masing-masing pertanyan ada 5 item jawaban.

\section{HASIL PENELITIAN Karakteristik Responden}

Tabel. 1

Karakteristik Responden

Berdasarkan Jenis Kelamin

\begin{tabular}{clcc}
\hline No & Jenis Kelamin & Frekuensi (f) & Persentase (\%) \\
\hline 1 & Laki-laki & 16 & 35.6 \\
2 & Perempuan & 29 & 64.4 \\
\hline & Total & 45 & 100.0 \\
\hline
\end{tabular}

Berdasarkan tabel 1 ditemukan bahwa sebagian besar responden berjenis kelamin perempuan dengan jumlah sebanyak 29 orang responden (64.4\%).

Tabel. 2

Karakteristik Responden

Berdasarkan Usia Orang Tua

\begin{tabular}{ccccc}
\hline No & & Usia Orang Tua & Frekuensi (f) & Persentase (\%) \\
\hline 1 & $20-30$ & 9 & 20.0 \\
2 & $31-40$ & 18 & 40.0 \\
3 & $41-50$ & 17 & 37.8 \\
4 & $51-60$ & 1 & 2.2 \\
\hline \multicolumn{2}{r}{ Total } & 45 & 100.0 \\
\hline
\end{tabular}

Berdasarkan tabel 2 ditemukan bahwa sebagian besar responden berusia 31-40 tahun dengan jumlah sebanyak 18 orang responden $(40.0 \%)$.

Tabel. 3

Karakteristik Responden

Berdasarkan Tingkat Pendidikan Orang Tua

\begin{tabular}{|c|c|c|c|}
\hline No & Tingkat Pendidikan & Frekuensi (f) & Persentase $(\%)$ \\
\hline 1 & SD & 5 & 11.1 \\
\hline 2 & SLTP & 11 & 24.5 \\
\hline 3 & SLTA & 19 & 42.2 \\
\hline 4 & Perguruan Tinggi & 10 & 22.2 \\
\hline & Total & 45 & 100.0 \\
\hline
\end{tabular}


Berdasarkan tabel 3 ditemukan bahwa sebagian besar responden bertingkat pendidikan SLTA dengan jumlah sebanyak 19 orang responden (42.2\%).

Tabel. 4

Karakteristik Responden

Berdasarkan Pekerjaan Orang Tua

\begin{tabular}{|c|c|c|c|}
\hline No & Pekerjaan & Frekuensi (f) & Persentase (\%) \\
\hline 1 & Tidak Bekerja & 17 & 37.8 \\
\hline 2 & Wiraswasta & 19 & 42.2 \\
\hline 3 & Guru & 4 & 8.9 \\
\hline 4 & PNS & 2 & 4.4 \\
\hline 5 & Karyawan & 3 & 6.7 \\
\hline & Total & 45 & 100.0 \\
\hline
\end{tabular}

Berdasarkan tabel 4 ditemukan bahwa sebagian besar responden adalah wiraswasta yaitu sebanyak 19 orang responden (42.2\%).

Tabel. 5

Karakteristik Responden Kecemasan Orang Tua Berdasarkan Usia Anak

\begin{tabular}{clccc}
\hline No & & Usia Anak (tahun) & Frekuensi (f) & Persentase $(\%)$ \\
\hline 1 & 7 & 7 & 15.6 \\
2 & 8 & 13 & 28.9 \\
3 & 9 & 6 & 13.3 \\
4 & 10 & 6 & 13.3 \\
5 & 11 & 9 & 20.0 \\
6 & 12 & 4 & 8.9 \\
\hline & Total & 45 & 100.0 \\
\hline
\end{tabular}

Berdasarkan tabel 5 ditemukan bahwa sebagian besar responden memiliki anak berusia 8 tahun sebanyak 13 orang responden (28.9\%).

\section{Gambaran Kecemasan}

Tabel. 6

Karakteristik Responden

Berdasarkan Tingkat Kecemasan

\begin{tabular}{clcc}
\hline No & \multicolumn{1}{c}{ Tingkat Kecemasan } & Frekuensi (f) & Persentase (\%) \\
\hline 1 & Tidak Cemas & 5 & 11.1 \\
2 & Kecemasan Ringan & 37 & 82.2 \\
3 & Kecemasan Sedang & 3 & 6.7 \\
4 & Kecemasan Berat & 0 & 0 \\
5 & Panik & 0 & 0 \\
\hline & Total & 45 & 100.0 \\
\hline
\end{tabular}

Dari tabel 6 ditemukan bahwa sebagian besar responden memiliki tingkat kecemasan dalam ketegori kecemasan ringan dengan jumlah sebanyak 37 orang responden (82.2\%). 


\section{PEMBAHASAN}

\section{Karakteristik Responden}

Dari hasil penelitian pada tabel 1 ditemukan bahwa jenis kelamin responden yang paling banyak mengalami kecemasan adalah perempuan dengan tingkat kecemasan ringan. Didukung oleh hasil penelitian yang dilakukan Natalya (2020) didapatkan jenis kelamin perempuan lebih banyak mengalami kecemasan jika dibandingkan dengan laki-laki. Hal tersebut bisa disebabkan karena total sampel yang masuk pun di dominasi oleh perempuan. Selain itu berdasarkan hasil penelitian Erdoğdu et al., (2020) wanita memiliki tingkat kecemasan yang jauh lebih tinggi dibandingkan pria. Berdasarkan penelitian (Lamba et al., 2017) mengungkapkan bahwa kategori jenis kelamin yang lebih rentan mengelami kecemasan ialah perempuan dengan jumlah 19 orang (63.3\%). Perempuan akan lebih rentan merasa cemas dibanding dengan laki-laki. Karena jika pada perempuan kecemasan secara berlebihan, akan menyebabkan gangguan fungsi emosional. Strategi komperehensif untuk menyaring masalah psikologis dan untuk mendukung kelompok berisiko tinggi sangat penting terutama wanita, orang dewasa paruh baya dan orang tua (Le et al., 2020).

Dari hasil penelitian pada tabel 2 didapatkan bahwa rentang usia responden yang paling banyak mengalami kecemasan adalah 31-40 tahun dengan tingkat kecemasan ringan. Dari hasil hasil penelitian yang dilakukan oleh Natalya (2020) menunjukan bahwa kategori usia yang paling mendominasi mengalami kecemasan adalah usia dewasa dan kedua disusul dengan usia remaja. Klasifikasi kelompok umur manusia dibagi menjadi 4 yaitu kanakkanak (5-11 tahun), remaja (12-25 tahun), dewasa (26-45 tahun), dan lansia (46-65 tahun) (Amin \& Juniati, 2017).

Selain itu berdasarkan hasil penelitian yang dilakukan oleh Demur (2020) didapatkan bahwa responden dengan usia dewasa madya mempunyi peluang 4,857 kali untuk mengalami kecemasan. Menurut asumsinya semakin bertambahnya usia seseorang akan mengalami kesehatan yang tidak seimbang serta akan berdampak pada psikologisnya seperti mengalami kecemasan.

Tingkat kecemasan dipengaruhi juga oleh karakteristik diantaranya adalah jenis kelamin, usia, pendidikan dan pekerjaan. Umur atau usia secara fisiologis pertumbuhan dan perkembangan seseorang dapat digambarkan dengan pertambahan usia. Pertambahan usia diharapkan terjadi pertambahan kemampuan motorik sesuai dengan tumbuh kembangnya.

Dari hasil penelitian pada tabel 3 ditemukan bahwa kecemasan lebih banyak dialami oleh responden yang berpendidikan SLTA dengan tingkat kecemasan ringan. Tingkat pendidikan seseorang juga berpengaruh dalam memberikan respon terhadap sesuatu yang datang baik dari dalam maupun dari luar. Pengetahuan diperoleh dari pendidikan, semakin tinggi pendidikan maka dapat memberikan pengetahuan lebih baik dibandingkan mereka yang berpengetahuan rendah, sehingga yang berpengethuan lebih baik akan semakin paham dnegan materi strategi dan mampu menerapkan (Riyadi \& Sundari, 2020).

Menurut Setyaningsih \& Anggasari (2017) faktor-fator yang mempengarusi tingkat pengetahuan salah satunya adalah pendidikan. Dengan pendidikan tingkat menegah dimungkinkan responden memperoleh informasi lebih banyak dari pada responden dengan pendidikan yang lebih rendah. Berdasarkan hasil penelitian yang dilakukan oleh Imelda (2017) menjelaskan bahwa pengetahuan yang kurang baik dilatarbelakangi oleh pendidikan terakhir yang rendah. Hal ini juga sejalan dengan jurnal penelitian Intarti (2019) pengetahuan juga dipengaruhi oleh pendidikan, seseorang yang memiliki pendidikan tinggi akan semakin mudah mendapatkan informasi sehingga banyak pula pengetahuan yang dimilikinya. Sebaliknya jika tingkat pendidikannya rendah kemungkinan mereka akan 
mengalami kesulitan dalam menerima informasi terlebih mengaplikasikannya dalam kehidupan sehari-hari.

Dari hasil penelitian pada tabel 4 ditemukan bahwa kecemasan lebih banyak dialami oleh responden yang bekerja sebagai wiraswasta dengan tingkat kecemasan ringan. Pekerjaan adalah bidang yang digeluti seseorang untuk mendapatkan penghasilan. Lama bekerja dapat mempengaruhi kinerja dan kepuasan kerja sehingga orang tersebut akan menyenangi pekerjaannya tanpa mementingkan kepentingan kesehatan, sehingga kemungkinan menularkan dan tertular penyakit sangat besar (Sujati, 2018).

Didukung oleh hasil penelitian yang dilakukan Le et al., (2020) dampak psikologis terkait COVID-19 terhadap wiraswasta, pengangguran, pensiunan dikaitkan dengan skor intrusi dan subskala hyperarousal yang lebih tinggi. Selain itu berdasarkan hasil penelitian yang dilakukan oleh Natalya (2020) mayoritas warga yang mengalami kecemasan yang lebih tinggi adalah bekerja sebagai wiraswasta. Berdasarkan hasil penelitian yang dilakukan oleh Demur (2020) didapatkan lebih dari separoh responden yang mengalami kecemasan adalah responden yang memiliki pekerjaan. Pekerjaan sangatlah berpengaruh terhadap kenyaman, kecemasan serta kualitas tidur, orang yang bekerja memiliki beban pikiran yang cukup besar terhadap pekerjaannya sehingga akan mempengaruhi kondisi psikologisnya.

Tingkat depresi, kecemasan dan stres orang tua dengan tingkat ekonomi keluarga rendah secara signifikan lebih tinggi dibandingkan dengan mereka yang memiliki tingkat ekonomi tinggi, kondisi ekonomi keluarga merupakan faktor penting yang mempengaruhi kesehatan mental individu. Dalam kasus pandemi, pendapatan masyarakat dipengaruhi dalam berbagai tingkatan. Keluarga dengan tingkat ekonomi yang lebih rendah akan lebih terpengaruh, yang dapat menyebabkan lebih banyak respons stres, kecemasan, dan depresi di antara orang tua ini (Wu et al., 2020).

Dari hasil penelitian pada tabel 5 ditemukan bahwa kecemasan lebih banyak dialami oleh responden yang memiliki anak berusia 8 tahun, dengan tingkat kecemasan ringan. Berdasarkan hasil penelitian yang dilakukan oleh Tirajoh et al., (2021) rasa cemas yang di rasakan lebih besar dialami pada orang tua siswa SD, SMP, SMA dibandingkan orang tua mahasiswa, hasil SAS juga didapatkan 10,8\% orang tua anak sekolah dasar mengalami peningkatan kecemasan. Faktor lain yang mempengaruhi tingkat depresi orang tua yaitu kecemasan dan stress yang dirasakan dalam kepuasan pernikahan, dukungan sosial, riwayat penyakit jiwa dan gaya pengasuhan terhadap anak.

Menurut penelitian Wu et al., (2020) tingkat deteksi depresi dan kecemasan pada orang tua adalah $6,1 \%$ dan 4,0\%. Selain itu berdasarkan penelitian Brown et al., (2020) menambahkan orang tua mengalami stressor kumulatif akibat COVID-19. Mengenai stressor spesifik, sekitar $21 \%-47 \%$ orang tua melaporkan bahwa anak mereka masingmasing mengalami perubahan pada kesehatan dan pembelajaran akibat COVID-19. Stressor yang paling umum terjadi pada orang tua termasuk pada perubahan suasana hati dan tingkat stress secara umum. Demikian pula, mayoritas orang tua dilaporkan mengalami gejala kecemasan dan depresi serta kurang tidur.

Teori belajar mempercayai bahwa seseorang yang telah terpapar kekhawatiran yang intens dalam kehidupan awal lebih cenderung mengalami kecemasan di kemudian hari, sehingga pengaruh orang tua adalah penting. Anak-anak yang melihat orang tua mereka merespon dengan kekhawatiran pada stres ringan segera mengembangkan pola yang sama. Sebaiknya, jika orang tua tidak tergerak oleh situasi yang berpotensi stress, anak-anak merasa sendirian dan kehilangan dukungan emosional dari keluarga mereka. Respon emosional yang tepat dari orang tua memberikan anak-anak rasa aman dan membantu mereka belajar metode koping konstruktif. 
Penelitian yang dilakukan Aini et al., (2021) terdapat hubungan antara perilaku orang tua terhadap pencegahan COVID-19 pada anak dengan tingkat hubungan yang cukup kuat dan berperilaku yang positif, dimana makin bertambah usia anak maka meningkatkan perilaku orang tua terhadap COVID-19. Terdapat beberapa faktor yang dapat mempengaruhi sebuah perilaku orang tua. Kegiatan yang dilakukan oleh anak lebih besar adalah bermain. Sebuah kegiatan pencegahan yang dapat dilakukan dengan interaksi dan stimulasi yang meliputi keterampilan kognitif, motorik dan psikomotor yang dilaksanaak secara terpadu untuk mencapai hasil yang maksimal. Terdapat beberapa hal yang dapat mempengaruhi sebuah keberhasilan orang tua dalam melakukan proses pencegahan yaitu pengetahuan orang tua, tingkat pendidikan, sosial ekonomi, budaya, lingkungan sekitar dan sumber informasi.

\section{Gambaran Pengetahuan Stimulasi Responden}

Dari hasil penelitian pada tabel 6 diperoleh hasil bahwa sebagian besar responden mengalami tingkat kecemasan ringan. Kecemasan adalah keadaan emosi yang tidak menyenangkan, melibatkan rasa takut subjektif, rasa tidak nyaman pada tubuh, dan gejala fisik. Kecemasan seringkali terdapat perasaan ancaman atau kematian yang akan terjadi, yang dapat ataupun tidak sebagai respon terhadap ancaman yang dapat dikenali.

Kecemasan ringan berhubungan dengan ketegangan peristiwa kehidupan sehari-hari. Lapang persepsi melebar dan orang akan bersikap hati-hati dan waspada. Orang yang mengalami kecemasan ringan akan terdorong untuk menghasilkan kreativitas. Responrespon fisiologis orang yang mengalami kecemasan ringan adalah mengalami nafas pendek, naiknya tekanan darah dan nadi, muka berkerut, bibir bergetar. Adapun respon perilaku dan emosi dari orang yang mengalami kecemasan ringan adalah tidak dapat duduk dengan tenang, tremor halus pad atangan, dan suara kadang-kadang meninggi. Didukung oleh hasil penelitian yang dilakukan Natalya (2020) diperoleh hasil bahwa sebanyak 99 orang responden $(49.0 \%)$ mengalami kecemasan ringan.

Selain itu berdasarkan hasil penelitian yang dilakukan Wu et al., (2020) didapatkan bahwa tingkat kecemasan tertinggi orang tua yaitu gejala kecemasan ringan menyumbang 20,7\%, gejala kecemasan sedang menyumbang 3,4\% dan gejala kecemasan berat menyumbang $0,5 \%$. Kecemasan yang dialami oleh orang tua, walaupun bisa berdampak psikologis tetapi bisa diatasi jika orang tua berusaha untuk mencari pertolongan (Tirajoh et al., 2021).

Beberapa penelitian telah berfokus pada kesehatan mental orang tua siswa. Karena COVID-19 sangat menular, dan masih kurangnya sarana pengobatan yang efektif, inti dari pencegahan adalah mengurangi berkumpulnya massa. Dalam kebijakan kepemimpinan pusat, masyarakat mulai lama menjalani karantina di rumah, orang tua dan anak harus bekerja dan belajar di rumah. Orang tua dan anak-anak dibatasi ruang terbatas. Dalam konsultasi online saat pandemi COVID-19, para orang tua menanyakan banyak masalah praktis seperti bagaimana bergaul dengan anak dan bagaimana menangani konflik dengan anak. Banyak orang tua berpartisipasi dalam ceramah jaringan yang relevan untuk meningkatkan komunikasi dengan anak-anak, meredakan konflik keluarga orang tua-anak dan meningkatkan kualitas hubungan orang tua-anak. Selain stres yang disebabkan oleh pandemi, hubungan orang tua-anak dan hubungan antara orang tua juga mempengaruhi kesehatan mental orang tua dalam masa yang sulit, dan kesehatan mental orang tua selanjutnya dapat mempengaruhi kesehatan mental dan fisik anak, sehingga menimbulkan ganas. lingkaran. Oleh karena itu, kesehatan mental orang tua sangat perlu diwaspadai saat terjadi pandemi COVID-19 (Wu et al., 2020). 


\section{SIMPULAN}

Gambaran tingkat kecemasan orang tua ketika anak berinteraksi sosial dimasa pandemic COVID-19 di wilayah kerja Puskesmas Beringin Raya Kota Bengkulu tergolong tingkat kecemasan ringan.

\section{SARAN \\ Bagi Orang Tua/Pengasuh Anak}

Disarankan bagi orang tua/pengasuh yang mengalami kecemasan agar selalu mengikuti protokol kesehatan, menggunakan alat pelindung diri seperti masker, handsanitizer, sabun cuci tangan dan anti septik, menghindari kerumunan orang banyak, istirahat yang cukup, konsumsi makanan yang bergizi, melakukan aktivitas seperti berolahraga, memilih informasi yang tepat terkait dengan pandemi COVID-19 serta menciptakan lingkungan bermain dan lingkungan yang nyaman bagi anak.

\section{Bagi Peneliti Selanjutnya}

Bagi peneliti selanjutnya bisa meneliti tentang faktor-faktor yang berperan dalam menimbulkan kecemasan orang tua/pengasuh saat mengahadapi pandemic COVID-19 dan menjadikan penelitian ini sebagai referensi untuk melakukan penelitian sejenis dan melanjutkan hal-hal yang belum diteliti oleh peneliti dalam bidang yang sama.

\section{DAFTAR PUSTAKA}

Aini, N., Anggraini, I. R., \& Alifatin, A. (2021). Perilaku Orang Tua dalam Upaya Pencegahan COVID-19 pada Anak. Jurnal Insan Cendekia, 8(1), 49-54. https://doi.org/10.35874/jic.v8i1.813

Amin, M. A., \& Juniati, D. (2017). Klasifikasi Kelompok Umur Manusia Berdasarkan Analisis Dimensi Fraktal Box Counting dari Citra Wajah dengan Deteksi Tepi Canny. Jurnal Ilmiah Matematika, 2(6), 33-42. https://media.neliti.com/media/publications/249455-none-23b6a822.pdf

Andri, J., Padila, P., \& Arifin, N. A. W. (2021). Tingkat Kecemasan Pasien Kardiovaskuler pada Masa Pandemi COVID-19. Journal of Telenursing (JOTING), 3(1), 382-389. https://journal.ipm2kpe.or.id/index.php/JOTING/article/view/2167

Brown, S. M., Doom, J. R., Lechuga-Peña, S., Watamura, S. E., \& Koppels, T. (2020). Stress and Parenting During the Global COVID-19 Pandemic. Child Abuse and Neglect, 110(2), 104699. https://doi.org/10.1016/j.chiabu.2020.104699

Demur, D. R. D. N. (2020). Hubungan Karakteristik Dengan Tingkat Kecemasan Pada Pasien Terpasang Infus Di Ruang Rawat Inap Interne. Jurnal Kesehatan Medika Saintika, 11(1), 16. https://doi.org/10.30633/jkms.v11i1.504

Erdoğdu, Y., Koçoğlu, F., \& Sevim, C. (2020). An Investigation of the Psychosocial and Demographic Determinants of Anxiety and Hopelessness During COVID-19 Pandemic. Klinik Psikiyatri Dergisi, 23, 24-37. https://doi.org/10.5505/kpd.2020.35403

Gugus COVID-19. (2020). Perkembangan Kasus Provinsi Bengkulu.

Iftitah, S. L., \& Anawaty, M. F. (2020). Peran Orang Tua dalam Mendampingi Anak di Rumah Selama Pandemi COVID-19. JCE (Journal of Childhood Education), 4(2), 71. https://doi.org/10.30736/jce.v4i2.256 
Imelda, I. (2017). Pengetahuan Ibu tentang Pemberian Stimulasi dan Perkembangan Anak Pra Sekolah (3-5 Tahun) di Banda Aceh. Idea Nursing Journal, 8(3), 1-9. http://jurnal.unsyiah.ac.id/INJ/article/view/9487/7946

Intarti, W. D. (2019). Pengaruh KIE terhadap Tingkat Pengetahuan Guru PAUD tentang Stimulasi Kecerdasan Otak Anak Usia Dini. Jurnal Kebidanan Harapan Ibu Pekalongan, 6(2), 202-212. https://doi.org/10.37402/jurbidhip.vol6.iss2.56

Kemenkes RI. (2020). Pedoman Pencegahan dan Pengendalian Coronavirus Disease (COVID-19). Germas, 0-115. https://COVID19.kemkes.go.id/protokol-COVID19/kmk-no-hk-01-07-menkes-413-2020-ttg-pedoman-pencegahan-danpengendalian-COVID-19

Lamba, C. T., Munayang, H., \& Kandou, L. F. J. (2017). Gambaran Tingkat Kecemasan pada Warga yang Tinggal di Daerah Rawan Banjir Khususnya Warga di Kelurahan Tikala Ares Kota Manado. E-CliniC, 5(1), 61-65. https://doi.org/10.35790/ecl.5.1.2017.15526

Le, X. T. T., Dang, A. K., Toweh, J., Nguyen, Q. N., Le, H. T., Do, T. T. T., Phan, H. B. T., Nguyen, T. T., Pham, Q. T., Ta, N. K. T., Nguyen, Q. T., Nguyen, A. N., Van Duong, Q., Hoang, M. T., Pham, H. Q., Vu, L. G., Tran, B. X., Latkin, C. A., Ho, C. S. H., \& Ho, R. C. M. (2020). Evaluating the Psychological Impacts Related to COVID-19 of Vietnamese People Under the First Nationwide Partial Lockdown in Vietnam. Frontiers in Psychiatry, 11. https://doi.org/10.3389/fpsyt.2020.00824

Megatsari, H. (2020). Gangguan Kecemasan Masyarakat Indonesia Selama Pandemi COVID-19. Unair. ws.unair.ac.id/2020/10/23

Natalya, W. (2020). Gambaran Tingkat Kecemasan Warga Terdampak COVID 19 di Kecamatan Comal Kabupaten Pem. University Research Colloqium, 458-463. http://repository.urecol.org/index.php/proceeding/article/view/1230/1198

Padila, P., Andri, J., Sartika, A., Andrianto, M, B., \& Harsismanto, J. (2021). Pengalaman Single Parents dalam Merawat Anak yang Terkonfirmasi Positif COVID-19. Jurnal Kesmas Asclepius, 3(2), 41-48. https:// doi.org/10.31539/ jka.v3i2. 2896

Padila, P., Panzilion, P., Andri, J., Nurhayati, N., \& Harsismanto, J. (2021). Pengalaman Ibu Usia Remaja Melahirkan Anak di Masa Pandemi COVID-19. Journal of Telenursing (JOTING), 3(1), 63-72. https://doi.org/10.31539/joting.v3i1.2075

Riyadi, E. K. S., \& Sundari, S. (2020). Tingkat Pengetahuan Orang Tua tentang Stimulasi Perkembangan Anak Pra Sekolah Usia 60-72 Bulan. Jurnal Ilmu Kebidanan, 6(2), 59-67. http://jurnal.akbiduk.ac.id/assets/doc/210106120403-02

Setyaningsih, R., \& Anggasari, N. (2017). Hubungan Tingkat Pengetahuan Orang Tua tentang Stimulasi Verbal dengan Pekembangan Bahasa pada Anak Usia Dini di TK Yayasan Bhakti Siwi Desa Soran Kabupaten Klaten. KOSALA : Jurnal Ilmu Kesehatan, 5(2), 83-90. https://doi.org/10.37831/jik.v5i2.129

Sujati, Y. G. (2018). Kepuasan Kerja: Arti Penting, Faktor-Faktor yang Mempengaruhi dan Implikasinya Bagi Orgnisasi. Universitas Sanata Dharma. https://repository.usd.ac.id/31114/

Tirajoh, C. V., Munayang, H., \& Karupan, B. H. R. (2021). Dampak Pembelajaran Jarak Jauh terhadap Kecemasan Orang Tua Murid di Masa Pandemi COVID-19. Jurnal Biomedik: JBM, 13(1), 49-57. https://doi.org/10.35790/jbm.13.1.2021.31715 
Tursina, A. (2020). COVID-19 dan Lansia (Pusat Pene). https://lppm.unisba.ac.id/pusatpenerbitan-unisba-p $2 \mathrm{u} /$

WHO. (2020). Report of the WHO-China Joint Mission on Coronavirus Disease 2019 (COVID-19). The WHO-China Joint Mission on Coronavirus Disease 2019, 2019(February), 16-24. https://www.who.int/docs/defaultsource/coronaviruse/who-china-joint-mission-on-COVID-19-final-report.pdf

Wu, M., Xu, W., Yao, Y., Zhang, L., Guo, L., Fan, J., \& Chen, J. (2020). Mental Health Status of Students' Parents During COVID-19 Pandemic and Its Influence Factors. General Psychiatry, 33(4), e100250. https://doi.org/10.1136/gpsych2020-100250 